DOI https://doi.org/10.15407/usim.2020.01.060

UDC $61.616-71$

L.S. FAINZILBERG, D.Sc. (Engineering), Professor, Chief Researcher, International Research and Training Center for Information Technologies and Systems of the National Academy of Sciences of Ukraine and Ministry of Education and Science of Ukraine, Acad. Glushkova av., 40, Kiev, 03187, Ukraine, fainzilberg@gmail.com

\title{
EXPANDING OF INTELLECTUAL POSSIBILITIES OF DIGITAL TONOMETERS FOR HOME USING
}

The purpose of the article is to expand the intellectual capabilities of digital blood pressure monitors, which will increase the efficiency of their use at home. The proposed approach boils down to simple computational procedures that can be implemented on the internal processor of a home blood pressure monitor. It is shown that to assess long-term variability of indicators, it is enough to use the recurrence formulas for each current measurement to correct the range of recorded values, refine the mean and standard deviation, calculate the Pearson coefficient of variation and the index characterizing the percentage of measurements that exceed established medical standards.

Keywords: home blood pressure monitor, vascular elasticity, oscillations, blood pressure variability.

\section{Introduction}

Arterial hypertension (high blood pressure) is one of the most common diseases of the cardio-vascular system that suffer about $30 \%$ of the adult population [1]. The prevalence of diseases increases and reaches $65 \%$ among people over 65 years old [2]. With untimely diagnosis and treatment, the disease can cause serious complications - myocardial infarction and cerebral stroke, which often result the patient's death or disability.

Diagnosis and evaluating the effectiveness of arterial hypertension treatment primarily involves the measurement of blood pressure (BP) [3]. The auscultative method of measuring using the cuff and tonometer Riva-Rocci has been used in medical practice for more than a hundred years. With a decrease in pressure in the cuff, when the blood begins to pass through the squeezed section of the vessel, vortices and turbulence appear, creating characteristic sounds (Korotkov tones) that are heard in the phonendoscope and determine the levels of systolic and diastolic blood pressure.
Due to its accuracy, simplicity and accessibility, the Korotkov method has become the gold standard and is recommended by the World Health Organization for worldwide use.

Along with the advantages, the auscultative method has a number of disadvantages that limit its use at home [4]. Firstly, listening to Korotkov's tones requires certain qualifications, especially when measuring the patients' blood pressure with the so-called effects of "acoustic failure" or "infinite tone, which, according to statistics, are found in $7 \%$ of patients. Secondly, even with typical Korotkov tones, the measurement accuracy substantially depends on the location of the phonendoscope on the arteries, and the error increases significantly when measured through clothing. And finally, the main drawback of the Korotkov method is the complexity of the measurement automation, which makes it difficult to build reliable digital blood pressure monitors for home use.

Control at home provides the possibility of longterm monitoring, which is extremely important both for the prevention of arterial hypertension 
and for further monitoring after discharge of patients from the hospital. Therefore, home observation, without pretending to replace the traditional clinical measurement, is an informative method for clarifying the diagnosis in most clinical situations, especially in people with suspected "masked hypertension".

Recently, the market of medical devices for home use has been developing rapidly [5-7]. A significant place in this market is occupied by home blood pressure monitors, which allow individuals without special medical training to independently control blood pressure [8-10].

In such tonometers, the oscillometric method of measurement is most often used, it is based on recording the amplitude of the pulsations of air pressure at the time of passage of blood through the portion of the artery squeezed by the cuff. The method allows you to automatically measure with weak tones of Korotkov, in the presence of the phenomenon of "auscultation failure" and other effects that are difficult for the process of automation of measurement by the Korotkov method.

In addition, the oscillometric method can be used at a high noise level, its results are almost independent of the turn and movement of the cuff along the arm, and the measurement accuracy does not decrease when determined through the thin fabric of clothes.

Digital tonometers based on the oscillometric method are constantly being improved. Recently, a new generation of devices for home use has appeared, in which intelligent technologies are implemented that provide protection against errors in various arrhythmias, including arterial fibrillation, weak pulses and other difficult situations. Tonometers of this class are represented on the medical equipment market by well-known companies Omron and Citizen (Japan), Mocrolife (Sweden), Medisana (Germany), Gamma (England) and several other companies.

Analysis of available publications shows that the intellectual capabilities of home blood pressure monitors are far from exhausted. The rapid development of microelectronics and intelligent methods for detecting subtle changes in signals of a complex shape against a background of interfe- rence make it possible today to realize a number of important additional functions in tonometers.

The purpose of this article is to further expand the intellectual capabilities of digital blood pressure monitors, which will increase the efficiency of their using at home.

\section{Integral assessment of blood vessel elasticity}

Human vascular system consists of veins, arteries and capillaries. The total length of the blood vessels of the human body is about 100 thousand kilometers, which is more than twice the length of the equator of the Earth.

Determination of the blood vessels properties is an important link for the early detection, prevention and treatment of cardiovascular diseases. Elastic vessels allow you to save the stroke volume of blood, reduce the load on the heart and ensure smooth movement of blood from vessels of large diameter to vessels of smaller diameter. As a result, the pulsating blood flow from the heart is converted into a continuous and even flow through the entire vascular bed, which is very important for the normal functioning of the body.

It is known that aging of the body is accompanied by a loss of elasticity of blood vessels [11]. An increase in arterial stiffness leads to an increase in the pulse wave propagation speed, and this factor is currently recognized as one of the main risk factors for hypertension and the occurrence of coronary heart disease [12-14].

In recent years, non-invasive rheography methods have become widespread [15], which provide automatic determination of the pulse wave propa-gation velocity and the other parameters of vascular stiffness, which carry information about the initial signs of cardiovascular pathologies. In clinical conditions, the pulse wave velocity (PWV) is determined using special sensors installed in the carotid and femoral arteries. In this case, the PWV is estimated by the value of the delay of the signal recorded by these sensors [16].

There is another way: PWV is estimated by the time between the moments of the appearance of a direct pulse wave 1 generated by the current heart 


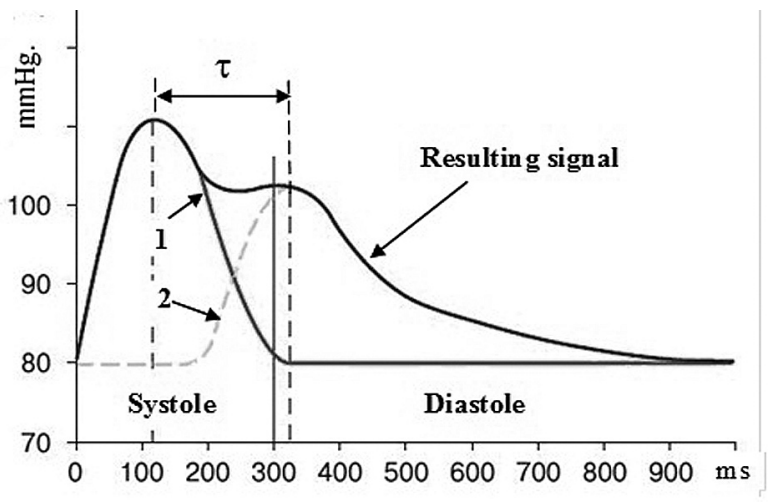

Fig. 1. Pressure in the bloodstream generated by forward 1 and backward 2 pulse waves
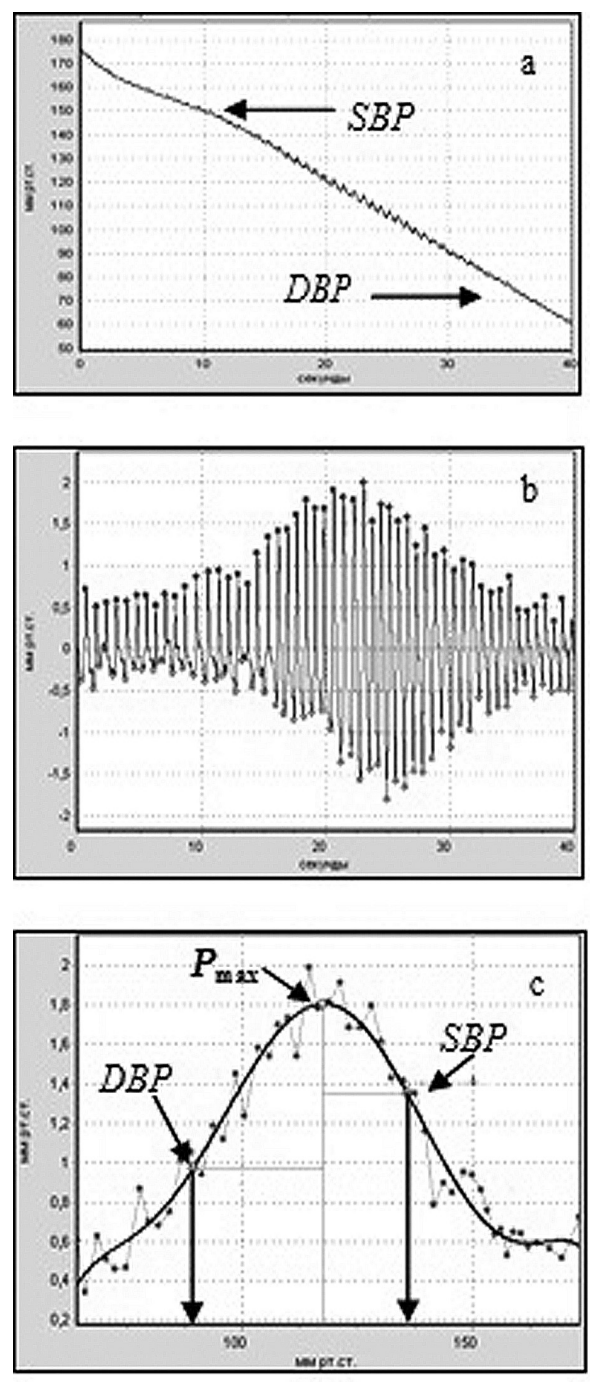

Fig. 2. The methodology of the oscillometric measurement method beat and a reverse pulse wave 2 reflected from the extremities (Fig. 1).

At the current contraction of the heart (systole), a wave of increased pressure occurs (direct pulse wave 1), which propagates through all blood vessels. Reaching the limbs, this wave is reflected and generates an "echo" wave" 2 , which propagates in the opposite direction of the vascular tree. With elastic arteries, the pulse wave propagation speed is relatively low and reflected wave 2 returns to the ascending aorta during the diastole (relaxation of the heart muscle). Such a delay is favorable, since in this case the reflected wave does not overlap the systolic phase and does not affect the systolic blood pressure.

On the contrary, with a decrease in vascular elasticity, the pulse wave propagation velocity increases. As a result, reflected wave 2 returns to the heart already in the systole period, which leads to an increase in systolic blood pressure, an increase in afterload on the heart, an increase in oxygen consumption by the myocardium and damage to arteries [17]. Therefore, an assessment of the elasticity of blood vessels can provide important information about the complex of risk factors for cardiovascular diseases [18].

Let us show that digital tonometers with a certain improvement tare able to provide information about the pulse wave propagation speed and thereby evaluate the integral stiffness index of blood vessels. To do this, we first consider some details of the oscillometric measurement method (Fig. 2).

Fig. 2. illustrates the methodology of the oscillometric measurement method:

a) a graph of changes in air pressure in the cuff;

b) signal after trend removal;

c) micropulsation (oscillation) of the signal during the measurement;

d) the calculation of the systole and diastole blood pressure levels by the "bell".

The initial data for the calculation is a finite sequence of discrete pressure values

$$
P_{1}, P_{2}, \ldots, P_{K} \text {, }
$$

which record during decompression from the initial value above the expected systolic to the final value below the estimated diastolic pressure (Fig. 2, a).

Recursive procedure 


$$
\begin{gathered}
\tilde{P}_{k}=\tilde{P}_{k-1}+\frac{1}{1+2 W_{0}}\left(P_{k+W_{0}}-P_{k-1-W_{0}}\right), \\
W_{0} \leq k \leq K-W_{0}
\end{gathered}
$$

with a sufficiently large window $W_{0}$ allows us to estimate the low-frequency trend of values and subtract it from the initial data (Fig. 2, b).

Further processing ensures the construction of the amplitudes array $\hat{Y}_{i}, i=1, \ldots, N$ of the signal micropulsations, the level of which exceeds a predetermined threshold of insensitivity. Using special procedures, a "bell" is constructed - an approximation dependence of the amplitudes $\hat{Y}, i=1, \ldots, N$ of micropulsations relative to the corresponding pressure levels during the decompression period. The systolic and diastolic pressure levels $P_{i}$ are estimated by the maximum $P_{\max }$ of this bell (Fig. 2,c) using the formulas

$$
\begin{aligned}
S P B & =q_{1} P_{\max }, \\
D B P & =q_{2} P_{\max },
\end{aligned}
$$

where $q_{1}, q_{2}$ are empirical coefficients.

Experimental studies have shown that the intelligent computational procedures, proposed in [19], make it possible by the signal $P(t)$ recorded during the decompression process to obtain not only the information necessary for measurement blood pressure levels, but also to "see" the fragments carrying information about pulse wave velocity. This gives us the key to the construction of a new generation of home blood pressure monitors, which allow the integral measurement of the stiffness of blood vessels during the measurement process [20].

Figure 3 shows a graph of the signal $P(t)$ during the cuff decompression. At pressures close to $S B P$ and $D B P$ fragments $F$ caused by the reflected pulse wave are observed on the oscillations. Such fragments have the characteristic shape and can be automatically detected using computer algorithms implemented on the internal processor of a home digital blood pressure monitor.

To determine the elasticity of the vessels, we calculate the time delays $\tau_{l}, l=1,2, \ldots$ between the moment when the corresponding oscillation takes the maximum value and the moment of appearance of the fragment $F$ caused by the reflected wave. Then, we determine the average value of time delays for a certain sequence $L$ of such oscillations:

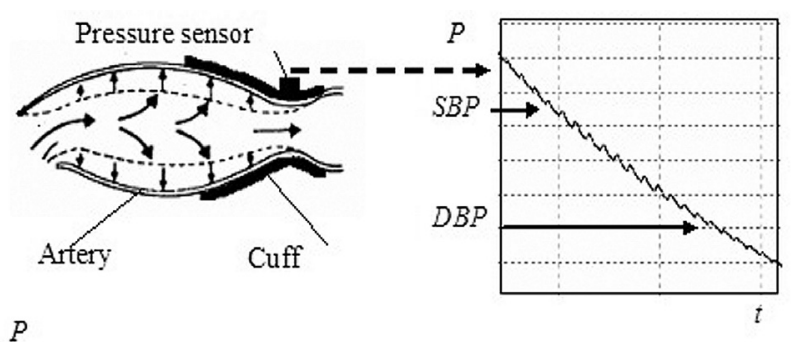

$P$

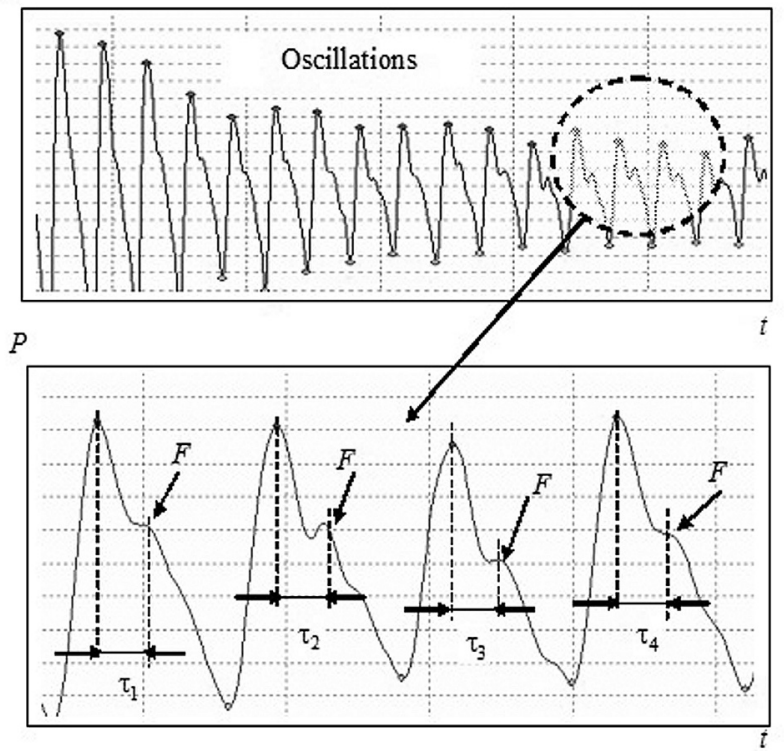

Fig. 3. Illustration of the proposed method

$$
\tau=\frac{1}{L} \sum_{l=1}^{L} \tau_{l}
$$

The obtained value makes it possible to determine the average propagation time of the pulse wave in the forward and reverse directions of blood flow, by which it is possible to integrally evaluate the elasticity of the patient's blood vessels (stiffness index) by formula

$$
I_{\Omega}=\frac{2 H}{\tau},
$$

where $H$ - patient height.

Checking the effectiveness of the proposed approach was carried out using a computer programme, the input of which received a sequence of (1) pressures during the oscillometric measurement using $B P$ by home tonometer. The stiffness index $I_{\Omega}$ was calculated according to the method described above, for which the programme implements computational procedures for searching and automatically recognizing fragments $F$ of oscillations generated by reflected waves. 

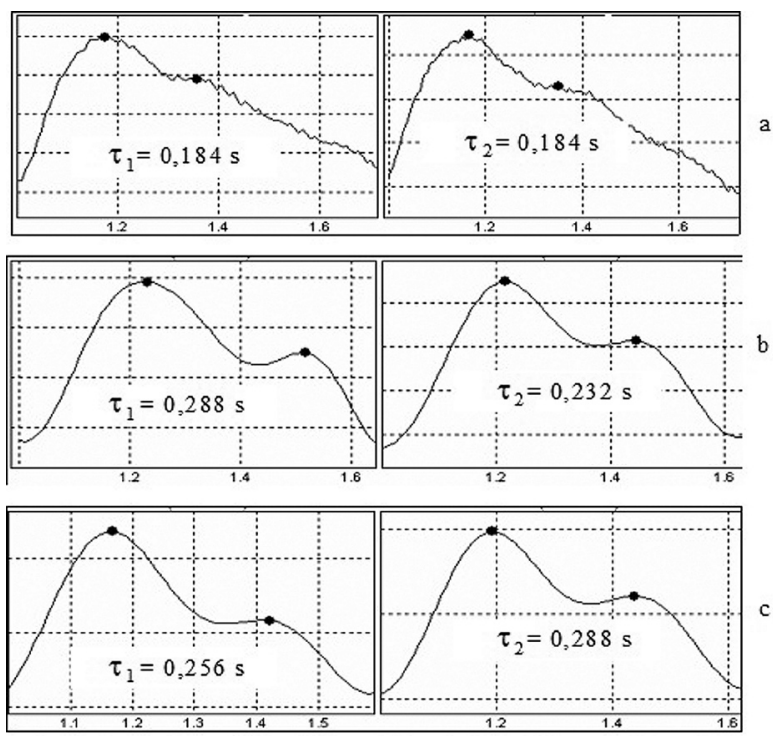

Fig. 4. Results of experiments on the calculation for different ages volunteers: 57 years old (a); 35 years old (b); 14 years old (c)

Experimental studies were conducted with a group of healthy volunteers (27 people of both sexes) of different age groups. Figure 4 shows the results of calculation experiments obtained from three healthy volunteers.

The first person was 57 years old, $H=1,76 \mathrm{~m}$. The time delays between the maximum values of the oscillations and the moments of the appearance of fragments generated by the reflected pulse wave in two successive oscillations were $\tau_{1}=\tau_{2}=0,184 \mathrm{~s}$ (Fig. 4, a). Therefore $=\tau=0,184 \mathrm{~s}$ and $I_{\Omega}=(2 \cdot 1,76) / 0,184=19,1 \mathrm{~m} / \mathrm{s}$.

The second volunteer was 35 years old, $H=$ $=1,78 \mathrm{~m}$. The time delays between the maximum values of the oscillations and the moments of the appearance of fragments generated by the reflected pulse wave in two successive oscillations were $\tau_{1}=0,288 \mathrm{~s}, \tau_{2}=0,232 \mathrm{~s}$ (Fig. 4, b). Therefore $\tau=0,26 \mathrm{~s}$ and $I_{\Omega}=(2 \cdot 1,78) / 0,26=13,7 \mathrm{~m} / \mathrm{s}$.

The third person was 14 years old, $H=1,65 \mathrm{~m}$. The time delays between the maximum values of the oscillations and the moments of the appearance of fragments generated by the reflected pulse wave in two successive oscillations were $\tau_{1}=0,256 \mathrm{~s}$, $\tau_{2}=0,288 \mathrm{~s}$ (Fig. 4, $c$ ).

Therefore $\tau=0,272 \mathrm{~s}$ and $I=(2 \cdot 1,65) / 0,272=$ $=12,1 \mathrm{~m} / \mathrm{s}$.

\section{4}

The results are consistent with the well-established notion of clinicians about increasing the value of the stiffness index as the body ages.

An analysis of the publications suggests that the pulse wave form carries information not only about vascular stiffness, but also about other important characteristics of the body [21]. Therefore, it is advisable to direct further research to the construction of diagnostic models that allow one to indirectly evaluate these characteristics in the process of oscillometric measurement BP and implement these models into home blood pressure monitor.

Let us consider one of the possible approaches to solving this problem.

By analogy with [22], let us approximate the resulting signal generated by the direct and reflected pulse waves (see Fig. 1) as the sum of the asymmetric Gaussian functions

$$
\begin{array}{r}
\hat{P}(t)=A_{1} \exp \left(-\frac{\left(t-\mu_{1}\right)^{2}}{2\left[b_{1}(t)\right]^{2}}\right)+A_{2} \exp \left(-\frac{\left(t-\mu_{2}\right)^{2}}{2\left[b_{2}(t)\right]^{2}}\right), \\
t=1,2, \ldots,
\end{array}
$$

in which

and

$$
\mu_{2}=\mu_{1}+\tau,
$$

$$
b_{i}(t)=\left\{\begin{array}{l}
b_{i}^{(1)}, \text { при } t \leq \mu_{i}, \\
b_{i}^{(2)}, \text { при } t>\mu_{i},
\end{array} \quad i=1,2 .\right.
$$

Next, we calculate the optimal values of eight parameters $A_{i}, \mu_{i}, b_{i}^{(1)}, b_{2}^{(1)}, i=1,2$ which are figuring in (7), which satisfying the criterion of the minimum mean square deviation of discrete values $\hat{P}(t)$ from the observed values $P(t)$. To determine the optimal values $A_{i}, \mu_{i}, b_{i}^{(1)}, b_{2}^{(1)}, i=1,2$ you may use the analytical method described in [22]. However, from a computational point of view, this method seems rather cumbersome for its implementation on the internal processor of a home blood pressure monitor.

But we may go the other way. The experiments showed that acceptable values $A_{i}, \mu_{i}, b_{i}^{(1)}, b_{2}^{(1)}, i=1,2$ can be found by a simple search procedure using a set of pretabulated exponential functions $y=e^{x}$ with different values of the argument $x$. As a result, the real signal generated by the direct and reflected waves uniquely encodes by totality of the parameters found (Fig. 5). 
As can be seen from fig. 5, the found optimal values of the parameters $A_{i}, \mu_{i}, b_{i}^{(1)}, b_{2}^{(1)}, i=1,2$ characterize the shape of the observed pulse wave quite well, which means that they can be used as arguments of models

$$
Z_{j}=Z_{j}\left(A_{i}, \mu_{i}, b_{i}^{(1)}, b_{i}^{(2)}\right), j=1, \ldots J,
$$

providing the indirect determination of physiological characteristics $Z_{j} \quad j=1, \ldots J$. Identification of such models is supposed by observation samples based on the inductive modeling methods [23].

\section{Assessment of blood pressure variability with a home blood pressure monitor}

It is known that most physiological parameters (pulse rate, blood pressure and many others) are subject to significant spontaneous fluctuations (true biological variability) [24, 25]. If such fluctuations lie within certain limits, then this is considered a physiological norm. According to [26], in practically healthy people aged 20 to 60 years, the daily variability in blood pressure is at least $10 \%$ of the average levels $S B P$ and $D B P$.

24 hour monitoring of blood pressure, which is carried out using the special devices, allows to determine the time intervals $T_{1}, T_{2}, \ldots$, when $B P$ exceeds the norm (Fig. 6), to evaluate the average values in the daytime and nighttime and a number of other indicators that carry valuable information in the diagnosis of hypertension [27].

Of course, 24 hour monitoring has a number of advantages compared to measuring blood pressure in a medical institution. The method allows to obtain a profile (series of values) $B P$ under conditions typical for the patient and thereby eliminate the so-called "white medical gown" effect. In addition, it becomes possible to identify patients with a high risk of cardiovascular complications due to the lack of an adequate reduction $B P$ at night and night time hypertension.

However, it is clear that 24 hour monitoring does not allow to assess the long-term variability $B P$ between visits to the doctor (so called visit-to-visit variability), which, according to the doctors, is very important for making the right diagnostic decisions [28-31].
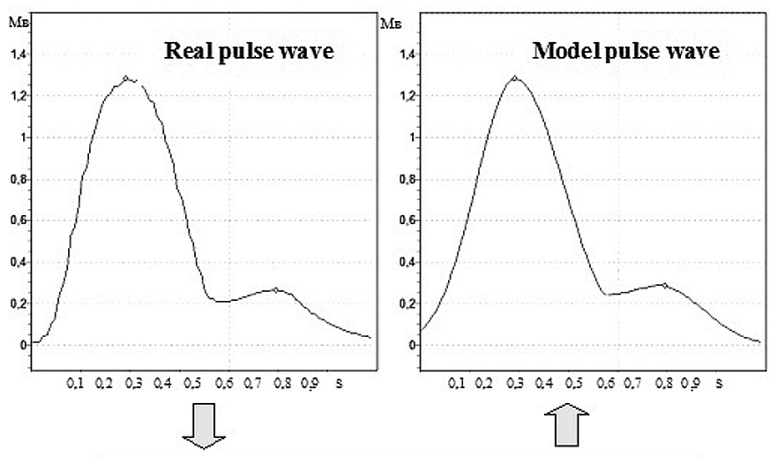

Optimal parameters $A_{i}, \mu_{\mathrm{i}}, b_{i}^{(1)}, b_{2}^{(1)}, i=1,2$

Fig. 5. The result of approximation of the real pulse wave by function (7)

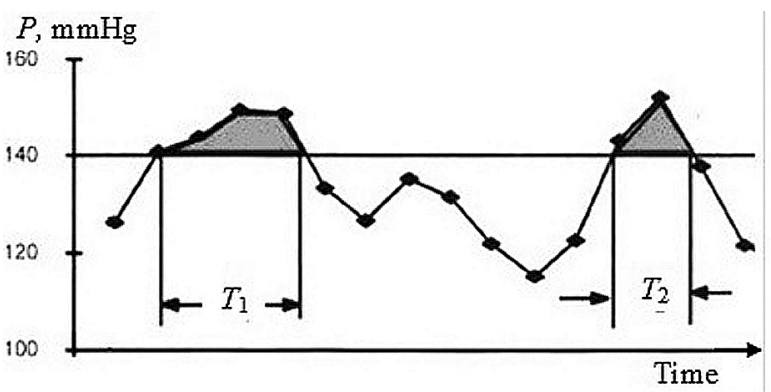

Fig. 6. Profile for 24 hour monitoring of blood pressure

Let us show that minor improvements to the home blood pressure monitor will provide the user with a number of additional useful functions that characterize the individual characteristics of ones pressure profile.

We will consider the values $S B P_{i}, i=1,2, \ldots$ of systolic blood pressure, which were observed in a particular user over a sufficiently large period of time (weeks, months, years), as the implementation of a random variable $P$ with a probability distribution $\mathfrak{R}_{S B P}$.

We denote the carrier of this distribution by the set

$$
\Omega_{S B P}=\left\{P: \Re_{S B P}>0\right\},
$$

and let $M_{S B P}$ be the average value of $S B P_{i}, i=1,2, \ldots$.

Let further $\Omega_{S B P}^{(0)}=[100,120]$ be the set (range) of normal values accepted in medical practice $S B P^{\mathrm{1}}$.

We consider four options for the mutual arrangement of sets and relative to the axis of values (Fig. 7).

Case 1. $\Omega_{S B P} \subset \Omega_{S B P}^{(0)}$, i.e. the range $\Omega_{S B P}$ of measured values is fully included in the normal range $\Omega_{S B P}^{(0)}$ of systolic blood pressure. 

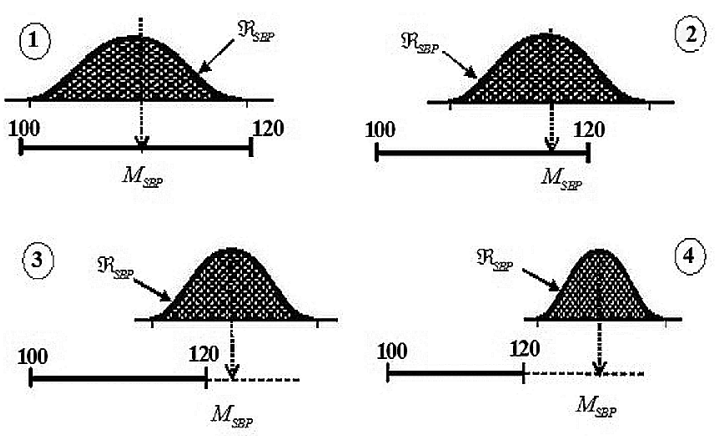

Fig. 7. The relative position of the sets $\Omega_{S B P}$ and $\Omega_{S B P}^{(0)}$

Case 2. $\left(\Omega_{S B P} \cap \Omega_{S B P}^{(0)}\right) \neq \varnothing, \Omega_{S B P} /\left(\Omega_{S B P} \cap \Omega_{S B P}^{(u)}\right) \neq$ $\neq \varnothing$, the range $\Omega_{S B P}$ partially enters the region $\Omega_{S B P}^{(0)}$, moreover $M_{S B P} \in \Omega_{S B P}^{(0)}$, i.e. the average of the measured values belongs to the normal range $\Omega_{S B P}^{(0)}$ of systolic blood pressure.

Case 3. $\left(\Omega_{S B P} \cap \Omega_{S B P}^{(0)}\right) \neq \varnothing, \Omega_{S B P} /\left(\Omega_{S B P} \cap \Omega_{S B P}^{(u)}\right) \neq$ $\neq \varnothing$, i.e. the range $\Omega_{S B P}$ partially enters to the region $\Omega_{S B P}^{(0)}$, moreover $M_{S B P} \notin \Omega_{S B P}^{(0)}$, i.e. the average of the measured values do not belong to the normal range $\Omega_{S B P}^{(0)}$ of systolic blood pressure.

Table 1. One of the option for generating quality information (when SBP > 100 mmHG)

\begin{tabular}{|c|c|c|c|}
\hline+ & Condition & $\begin{array}{c}\text { Text mes- } \\
\text { sage }\end{array}$ \\
\hline+ & $P_{1}, P_{2}, \ldots, P_{1}$ & $\begin{array}{c}\text { Dange- } \\
\text { rous } \\
\text { condition! }\end{array}$ \\
\hline+ & $0,5 \sigma_{S B P} \leq \Delta_{S B P} \leq$ & $\begin{array}{c}\text { Be } \\
\text { careful! } \\
\text { or }\end{array}$ & $\left|\Delta_{S B P}\right|<0,5 \sigma_{S B P}$ \\
\hline- & $\begin{array}{c}\text { Stable } \\
\text { condition! }\end{array}$ \\
\hline- & $\begin{array}{c}0,5 \sigma_{S B P} \leq \Delta_{S B P} \leq \\
\leq 1,5 \sigma_{S B P}\end{array}$ \\
\hline $\begin{array}{c}\text { The } \\
\text { condition } \\
\text { is impro- } \\
\text { ving }\end{array}$ \\
\hline $\begin{array}{c}\text { You are } \\
\text { in good } \\
\text { condition }\end{array}$
\end{tabular}

Case 4. $\left(\Omega_{S B P} \cap \Omega_{S B P}^{(0)}\right)=\varnothing$, those the range of measured values $\Omega_{S B P}$ extends beyond the normal range $\Omega_{S B P}^{(0)}$ of systolic blood pressure.

In the first case, the patient should be considered healthy. In the second case, the results of individual measurements did not correspond to the normal range $\Omega_{S B P}^{(0)}$. But since the average $M_{S B P}$ of the measured values belongs to the region $\Omega_{S B P}^{(0)}$, such a patient can be classified as conditionally healthy with a tendency to hypertension. In the third case, and especially in the fourth, there is nothing left to do but to attribute the patient to a group of patients with varying degrees of arterial hypertension.

Note that for the practical implementation of the proposed approach, it is not necessary to have the entire array of measured values. For each measurement $S P B_{i}$ it is enough to override the minimum $S B P_{\min }$ and maximum $S B P_{\max }$ of full array by scheme

$$
\begin{gathered}
S B P_{\min , i}=S P P_{i}, \text { if } S P P_{i}<S B P_{\min , i-1}, \\
S B P_{\max , i}=S P P_{i}, \text { if } S P P_{i}>S B P_{\max , i-1},
\end{gathered}
$$

and refine the current average $M_{S B P}$ using a recurrence formula $M_{S B P, i}=M_{S B P, i-1}+\frac{1}{i}\left[S B P_{i}-M_{S B P, i-1}\right]$,

by setting the initial conditions $M_{S B P, 0}=0$ and also $S B P_{\min , 0}=S B P_{\max , 0}=S B P_{0}$.

Applying the recurrence formula for calculating the modified random variance estimate for a sample of independent observations proposed in [32], it is also possible for each measurement $S B P_{i}, i=1,2, \ldots$ to reevaluate the current value of the mean square (standard) deviation $\sigma_{S B P}$ of the systolic blood pressure value for a particular patient.

To prevent distortion $S B P_{\min }, S B P_{\max }, M_{S B P}$ and $\sigma_{S B P}$ is advisable to provide an additional button in the tonometer, with which the user can block the recalculation of these values at the slightest suspicion of an error in the current result due to random artifacts.

With each measurement we can also calculate the current values of Pearson coefficient of variation

$$
V_{S B P}=\frac{\sigma_{S B M}}{M_{S B M}} \cdot 100 \%
$$

and index

$$
I_{S B P}=\frac{N_{S B P}^{(E)}}{N} \cdot 100 \%,
$$


characterizing the ratio of the number of measurements at which the systolic blood pressure exceeded the threshold $S B H=140 \mathrm{mmHg}$ to the total number of measurements.

In addition, with each measurement, we may calculate the value

$$
\Delta_{S B P, i}=S B P_{i}-M_{S B P}, i=1,2, \ldots
$$

characterizing the deviation of the current result $S B P_{i}$ from the previously found average value $M_{S B P}$, and compare the value $\Delta_{S B P, i}$ with the current value of the standard deviation $\sigma_{S B P}$.

As a result, with a simple refinement of the internal software, the home blood pressure monitor can additionally display on its screen quality information about the current functional state of the patient in the form of understandable graphic images (emoticons). One of the options for the formation of such information is presented in table 1 .

In a similar way, we can calculate the values $D B P_{\min }, D B P_{\max }, M_{D B P}, \sigma_{D B P}, V_{D B M}, I_{D B M}$ allowing us to estimate the variability of diastolic blood pressure $D B P_{i}, i=1,2, \ldots$.

To illustrate, consider an example of the formation of qualitative information in the analysis of systolic blood pressure.

Figure 8 shows a graph of the results of 85 measurements recorded over a period of three months using home tonometer by a patient who did not undergo antihypertensive therapy. Statistical characteristics of the results are summarized in table 2 .

Since the average value of the results is outside the range of the currently accepted norm $\left(M_{S B P}>120 \mathrm{mmHg}\right)$ this patient should be recognized as ill person (see Case 3 on Figure 7).

Figure 9 shows the areas of a qualitative assessment of the results, constructed according to the data of tables 1 and 2 .

A qualitative assessment of the results of blood pressure measurements, implemented in a home blood pressure monitor, helps a user who does not have a medical education make independent decisions aimed at optimizing his lifestyle, a reasonable distribution of the regime of load and rest, determine the need for additional intake of medications prescribed by a doctor, and evaluate possible dangerous situations requiring urgent medical attention.

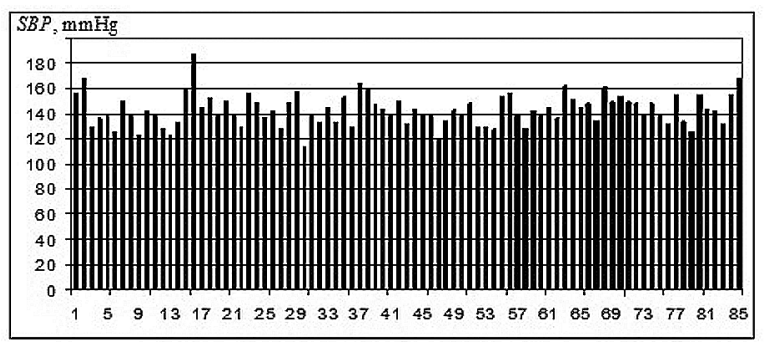

Fig. 8. Results of registration of systolic blood pressure by home tonometer

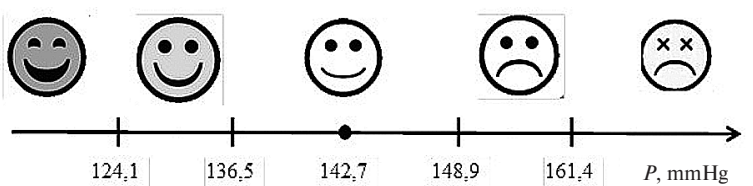

Fig 9. The example of qualitative assessment of the measurement results

Table 2. Statistical characteristics of the measurement results SBP, mmHG

\begin{tabular}{|c|c|c|c|c|}
\hline $\boldsymbol{S B P}_{\max }$ & $\boldsymbol{S B P}_{\text {min }}$ & $\boldsymbol{M}_{\mathrm{SBP}}$ & $\sigma_{S B P}$ & $\boldsymbol{V}_{S B P}(\%)$ \\
\hline 187 & 113 & 142,7 & 12,4 & 8,7 \\
\hline
\end{tabular}

Of course, the proposed approach in no way claims to replace, and even more so to cancel the established medical recommendations for the diagnosis and treatment of hypertension.

\section{Conclusion}

The article shows that the modern intelligent information technologies can implement a number of important additional functions for improving the efficiency of digital blood pressure monitors for home use.

It has been shown that directly in the process of the oscillometric method for determining blood pressure, home tonometers can provide the user an integrated assessment of the arterial stiffness index, which provides important diagnostic information about the complex of risk factors for cardiovascular diseases.

An approach has been proposed that allows us to assess the long-term variability of blood pressure indicators for self-measurement at home between visits to the doctor, which increases the reliability of decisions by eliminating the so-called "white medical gown" effect. 
It is shown that for the practical implementation of the proposed approach, it is sufficient to use the recurrence formulas for each current measurement to correct the range of recorded values, clarify the mean and standard deviation, calculate the Pear- son coefficient of variation and the index characterizing the percentage of measurements that exceed the established medical norms. Such calculations can easily be implemented on the internal processor of a home blood pressure monitor.

\section{REFERENCES}

1. Dilaveris, P.E., Richter, D.J., Gialafos, J.E., 1999. "Inadequate blood pressure control in a low risk Mediterranean population". European Heart Journal. Vol. 20, pp. 1845. DOI: 1053/euhj.1999.1847.

2. Klimov, A. V., Denisov, E. N., Ivanova, O. V., 2018. "Arterial hypertension and its prevalence among the population". Young scientist, 50, pp. 86-90 [Климов А. В., Денисов Е. Н., Иванова О. В. Артериальная гипертензия и ее распространенность среди населения. Молодой ученый. 2018. № 50. С. 86-90].

3. O'Brien, E., Waeber, B. et al., 2001. "Blood pressure measuring devices: recommendations of European Society of Hypertension". BMJ, 322, pp. 531-536. DOI: 10.1136/bmj.322.7285.531.

4. O'Brien, E., Petrie, J., Littler, W.A. et al., 1993. "The British Hypertension Society Protocol for the evaluation of blood pressure measuring devices". Journal of Hypertension, 11 (2), pp. 43-62. DOI: 1097/00004872-199007000-00004.

5. Ambulatory cardiac monitoring: Avoiding maturity through technological advancement, 2008. Market engineering research. Frost \& Sullivan, Meriland, 9, pp. 325.

6. Jordan, M., 2008. "Bringing medical devices home". Medical Device \& Diagnostic Industry Magazine, 30 (2), pp. 62-67.

7. Lewis, C., 2001. "Emerging trends in medical device technology: Home is where the heart monitor is." FDA Consumer, 35 (3), pp. 10-15.

8. Ward, A.M, Takahashi, O, Stevens, R, Heneghan, C.,2012. "Home measurement of blood pressure and cardiovascular disease: systematic review and meta-analysis of prospective studies". Journal of Hypertension, 30 (3), pp. 449-456. DOI: 10.1097/HJH.0b013e32834e4aed.

9. Cuspidi, C., Meani, S., Lonati, L. et al., 2005. "Prevalence of home blood pressure measurement among selected hypertensive patients: results of a multicenter survey from six hospital outpatient hypertension clinics in Italy". Blood pressure, 14 (4), pp. 251-256. DOI: 10.1080/ 08037050500210765.

10. Bancej, C.M, Campbell, N., McKay, D.W. et al., 2010. "Home blood pressure monitoring among Canadian adults with hypertension: results from the 2009 Survey on Living with Chronic Diseases in Canada". Canadian Journal of Cardioljgy, 26, (5), pp. 152-157. DOI: 1016/s0828-282x(10)70382-2.

11. Lehmann, E.D., 1993. "Elastic properties of the aorta. Lancet", 342, pp. 1417. DOI: 10.1016/0140-6736(93)92772-1.

12. Benetos, A, Laurent, S, Hoeks, AP, Boutotiyrie, P.H., Safar, M.E., 1993. "Arterial alterations with ageing and high blood pressure". A noninvasive study of carotid and femoral arteries. Arterioscler Thromb, 13, pp. 90-97. DOI: 1161/01. atv.13.1.90

13. Cameron, J.D., Jennings, Q.L., Dart, A.M., 1995. "The relationship between arterial compliance, age, blood pressure and serum lipid levels". Journal of Hypertension, 13, pp. 1718-1723.

14. Laurent,S, Boutouyrie, P, Asmar, R, et al., 2001. "Aortic stiffness is an independent predictor of all-cause and cardiovascular mortality in hypertensive patients". Hypertension, 37, pp. 1236-1241. DOI: 1161/01.hyp.37.5.1236.

15. Blacher, J., Asmar, R., Djane, S. et al., 1999. "Aortic pulse wave velocity as a marker of cardiovascular risk in hypertensive patients". Hypertension, 33 (5), pp. 1111-1117. DOI: 10.1161/01.hyp.33.5.1111.

16. Asmar, R., Benetos, A. Topouchian, J. et al., 1995. "Assessment of arterial distensibility by automatic pulse wave velocity measurement. Validation and clinical application studies". Hypertension, 26 (3), pp. 485-490, https://doi. org/10.1161/01.HYP.26.3.485.

17. Asmar, R., Topouchian, J., Pannier, B. et al., 2001. "Pulse wave velocity as endpoint in large-scale intervention trial. The Complior study". Journal of Hypertension, 19 (4), pp. 813-818, DOI: 1097/00004872-200104000-00019.

18. Vasyuk, Y.A., Ivanova, S.V., Shkolnik, E.L. et al., 2016. "Consensus of Russian experts on the assessment of arterial stiffness in clinical practice". Cardiovascular therapy and prevention, 15 (2), pp. 4-19, http://dx.doi.org/10.15829/17288800-2016-2-4-19.

19. Fainzilberg, L.S., 2008. Information technology for signal processing of complex shapes. Theory and practice. Kiev: Naukova Dumka, 333 р. [Файнзильберг Л.С. Информационные технологии обработки сигналов сложной формы. Теория и практика. Киев: Наукова Думка, 2008. 333 с].

20. Fainzilberg, L.S. Method for integral estimation of human blood vessels elasticity. Invention Patent of Ukraine No. 80757. 
Patents newsletter No. 17, 2007 [Файнзільберг Л.С. Спосіб інтегрального оцінювання еластичності кровоносних судин людини. Патент України на винахід № 80757. Бюл. № 17, 2007 р.].

21. Engendi, M., 2012. "On the Analysis of Fingertip Photoplethysmogram Signals. Current Cardiology Reviews", 8 (1), pp. 14-25. DOI: 2174/157340312801215782.

22. Fainzilberg, L.S., Matushevich, N.A., 2016. "An effective method for analyzing diagnostic signs by a noisy electrocardiogram". Upravlausie sistemy i masiny, 2, pp.76-84 [Файнзильберг Л.С., Матушевич Н.А. Эффективный метод анализа диагностических признаков по зашумленной электрокардиограмме. Управляющие системы и машины. 2016. № 2. С.76-84].

23. Stepashko, V.S., 2017. "Achievements and prospects of inductive modeling". Upravlausie sistemy i masiny, 2, pp. 5873 [Степашко В.С. Достижения и перспективы индуктивного моделирования. Управлячющие системы и машины. 2017. № 2. 58-73].

24. Stolarz-Skrzypek, K., Thijs, L., Richart, T., 2010. "Blood Pressure variability in relation to outcome in the International Database of Ambulatory blood pressure in relation to Cardiovascular Outcome". Hypertension Research, 33, pp. 757-766.

25. Malik, M., Camm, A.J., 1993. "Components of heart rate variability. What they really mean and what we really measure". American Journal of Cardioljgy, 72, pp. 821-822.

26. Voronin, I.M., Bazhenova, E.A., 2007. "Variability of blood pressure in normal and pathological conditions". Bulletin of the Tambov State University, 12 (1), pp. 179-181 [Воронин И.М., Баженова Е.А. Вариабельность артериального давления в норме и при патологии. Вестник Тамбовского Государственного Университета. 2007. Том 12. Вып.1. C. 179-181].

27. Rogoza, A.N., Agaltsov, M.V., Sergeeva, M.V., 2005. 24-hour monitoring of arterial pressure: options for medical opinions and comments. Nizhny Nozniy NovGorod: DECOM, 64 р. [Рогоза А. Н., Агальцов М. В., Сергеева М. В. Суточное мониторирование артериального давления: варианты врачебных заключений и комментарии. Нижний Новгород: ДЕКОМ, 2005. 64 с.].

28. Muntner, P., Shimbo, D., Tonelli, M., Reynolds, K., Arnett ,D.K., Oparil, S., 2011. "The relationship between visit-to-visit variability in systolic blood pressure and all-cause mortality in the general population: findings from NHANES III 1988 to 1994". Hypertension, 57, pp. 160-166, DOI: 1161/HYPERTENSIONAHA.110.162255.

29. Stergiou, G.S., Parati, G., Vlachopoulo, C. et al., 2016. "Methodology and technology for peripheral and central blood pressure and blood pressure variability measurement: current status and future directions - Position statement of the European Society of Hypertension Working Group on blood pressure monitoring and cardiovascular variability". Journal of Hypertension, 34 (9), pp. 1665-1677, DOI: 1097/HJH.0000000000000969.

30. Rothwell, P.M., 2011. "Does blood pressure variability modulate cardiovascular risk? Current Hypertension Reports", 13 (3), pp. 177-186, DOI: 1007/s11906-011-0201-3.

31. Mancia, G., 2007. "Effective Ambulatory Blood Pressure Control in Medical Practice", 49, pp.17-18, https://doi. org/10.1161/01.HYP.0000250560.27738.72

32. Zhukovskaya, O.A., Glushauskene, G.A., Fainzilberg, L.S., 2008. "Investigation of the properties of the modified estimation of the varianse by a sampling of independent random observations". Scientific News of NTU Ukraine KPI, 4, pp. 139-145 [Жуковська О.А., Глушаускенє Г.А., Файнзільберг Л.С. Дослідження властивостей модифікованої оцінки дисперсії випадкової величини за вибіркою незалежних спостережень. Наукові вісті НТУ України КПІ. 2008. № 4. С. 139-145].

Received 01.01.2020

Л.С. Файнзільберг, доктор техн. наук, професор, головний науковий співробітник,

Міжнародний науково-навчальний центр інформаційних технологій та систем НАН та МОН України, просп. Глушкова, 40, Київ 03187, Україна,

fainzilberg@gmail.com

\section{РОЗШИРЕННЯ ІНТЕЛЕКТУАЛЬНИХ МОЖЛИВОСТЕЙ ЦИФРОВИХ ТОНОМЕТРІВ ДЛЯ ДОМАШНЬОГО ВИКОРИСТАННЯ}

Вступ. Артеріальна гіпертензія (підвищений артеріального тиск) - одне з найпоширеніших захворювань серцевосудинної системи. Діагностика та оцінка ефективності лікування артеріальної гіпертензії передбачає вимірювання артеріального тиску, в тому числі за допомогою цифрових домашніх тонометрів. Однак інтелектуальні можливості таких тонометрів далеко не вичерпано. 
Fainzilberg L.S.

Мета статті - розширення інтелектуальних можливостей цифрових тонометрів, які забезпечать підвищення ефективності застосування їх у домашніх умовах.

Методи. Для досягнення поставленої мети сформульовано та досліджено два завдання. Перше завдання спрямовано на визначення можливості цифрового тонометра оцінити інтегральний показник (індекс) жорсткості кровоносних судин на основі визначення швидкості поширення пульсової хвилі за сигналом, що реєструється в процесі осцилометричного способу вимірювання артеріального тиску. Друге завдання орієнтовано на розробку простих засобів, що забезпечують оцінку тривалої варіабельності показників артеріального тиску при самостійному вимірюванні в домашніх умовах між відвідинами лікаря (visit-to-visitvariability).

Результати. Встановлено, що в процесі декомпресії манжети на осциляціях спостерігаються характерні фрагменти, викликані зворотною пульсовою хвилею, виявлення яких дає змогу обчислити інтегральний показник жорсткості кровоносних судин за швидкістю розповсюдження пульсової хвилі. Показано, що для оцінки тривалої варіабельності показників достатньо за допомогою рекурентних формул за кожним поточним вимірюванням коригувати діапазон зареєстрованих значень, уточнювати середнє та середнє квадратичне відхилення, обчислювати коефіцієнт варіації Пірсона та індекс, що характеризує відсоток вимірювань, що перевищують встановлені медичні норми.

Висновки. Запропонований підхід зводиться до простих обчислювальних процедур, які можуть бути реалізовані на внутрішньому процесорі домашнього тонометра.

Ключові слова: домашній тонометр, еластичність судин, осциляції, варіабельність артеріального тиску.

Л.С. Файнзильберг, д-р техн. наук, профессор, глав. науч. сотруд., Международный

научно-учебный центр информационных технологий и систем НАН и МОН Украины,

просп. Глушкова, 40, Киев 03187, Украина,

fainzilberg@gmail.com

\section{РАСШИРЕНИЕ ИНТЕЛЛЕКТУАЛЬНЫХ ВОЗМОЖНОСТЕЙ ЦИФРОВЫХ ТОНОМЕТРОВ ДЛЯ ДОМАШНЕГО ПРИМЕНЕНИЯ}

Введение. Артериальная гипертензия (повышенное артериального давление) - одно из наиболее распространённых заболеваний сердечно-сосудистой системы. Диагностика и оценка эффективности лечения артериальной гипертензии предполагает измерение артериального давления, в том числе с помощью цифровых домашних тонометров. Однако интеллектуальные возможности таких тонометров далеко не исчерпаны.

Цель статьи - ррасширение интеллектуальных возможностей цифровых тонометров, которые обеспечат повышение эффективности их применения в домашних условиях.

Методы. Для достижения поставленной цели сформулированы и исследованы две задачи. Первая задача направлена на определения возможности цифрового тонометра оценить интегральный показатель (индекс) жесткости кровеносных сосудов на основе определения скорости распространения пульсовой волны по сигналу, регистрируемому в процессе осциллометрического способа измерения артериального давления. Вторая задача ориентирована на разработку простых средств, обеспечивающих оценку долговременной вариабельности показателей артериального давления при самостоятельном измерении в домашних условиях между посещениями врача (visit-to-visit variability).

Результаты. Установлено, чтов процессе декомпрессии манжетки на осцилляциях наблюдаются характерные фрагменты, вызванные отраженной пульсовой волной, обнаружение которых позволяет вычислить интегральный показатель жесткости кровеносных сосудов по скорости распространения пульсовой волны. Показано, что для оценки долговременной вариабельности показателей достаточно с помощью рекуррентных формул по каждому текущему измерению корректировать диапазон зарегистрированных значений, уточнять среднее и среднеквадратическое отклонение, вычислять коэффициента вариации Пирсона и индекс, характеризующий процент измерений, превышающих установленные медицинские нормы.

Выводы. Предложенный подход сводится к простым вычислительным процедурам, которые могут быть реализованы на внутреннем процессоре домашнего тонометра.

Ключевые слова: домашний тонометр, эластичность сосудов, осцилляции, вариабельность артериального давления. 